\title{
Testimony, Holocaust Education and Making the Unthinkable Thinkable
}

\section{JUDITH SUISSA}

A great deal of philosophical work has explored the complex conceptual intersection between ethics and epistemology in the context of issues of testimony and belief, and much of this work has significant educational implications. In this paper, I discuss a troubling example of a case of testimony that seems to pose a problem for some established ways of thinking about these issues and that, in turn, suggests some equally troubling educational conclusions.

\section{JAN KARSKI AND EPISTEMIC INJUSTICE}

In 1942 Jan Karski, a senior courier with the Polish resistance, was smuggled into the Warsaw Ghetto and later, disguised as a Ukranian guard, into the Belzec death camp. In October that year, Karski reported on the atrocities that he had witnessed, first in London, to the Polish Government in exile and senior politicians, and then in Washington, to prominent US statesmen and public figures, including leaders of the American Jewish community. His meeting with Supreme Court Justice Felix Frankfurter, in the presence of the Polish Ambassador in Washington, Jan Ciechanowski, was related by Karski to Claude Lanzmann for his film Shoah, but edited out of the final version of the film. Following is an account of the meeting from Karski’s biography (Woods and Jankowski, 1996):

"There are so many conflicting reports about what is happening to the Jews in your country," Frankfurter said. "Please tell me exactly what you have seen." 
Jan spent half an hour patiently explaining how his missions to the Ghetto and the camp had come about and precisely, in gruesome detail, what he had witnessed. When Karski finished, he waited for the visitor to make the next move.

Frankfurter silently got up from his chair. For a few moments, he paced back and forth in front of Karski and the Ambassador, who looked on in puzzlement. Then, just as quietly, he took his seat again.

"Mr. Karski," Frankfurter said after a further pause, "A man like me talking to a man like you must be totally frank. So I must say: I am unable to believe you."

Ciechanowski flew from his seat. "Felix, you don't mean it!" he cried. "How can you call him a liar to his face! The authority of my government is behind him. You know who he is!"

Frankfurter replied, in a soft voice filled with resignation, "Mr. Ambassador, I did not say this young man is lying. I said I am unable to believe him. There is a difference."

Here we have what may seem, on the face of it, to be an instance of testimony that raises ethical issues along the lines identified by Miranda Fricker in her much-cited work on epistemic injustice (Fricker, 2007). In developing this notion, Fricker explains that testimonial injustice, which is a central form of epistemic injustice, occurs when "a prejudice causes a hearer to give a deflated level of credibility to a speaker's word."'(Fricker, 2007, 
p.1). She goes on to state: "The dysfunction of unduly deflated credibility may be not only an epistemic dysfunction, it may also be an ethical dysfunction. For the speaker who receives a prejudicially deflated degree of credibility from a hearer is thereby wronged - he is wronged specifically in his capacity as a knower.”(ibid, p. 20).

Credibility defects are not always the result of prejudice. They might sometimes, Fricker explains, "simply result from innocent error: error that is, in other words, both ethically and epistemically non-culpable. One reason why there will always be cases of innocent error is that human judgement is fallible, and so it is inevitable that even the most skilled and perceptive hearers will on occasion come up with a mistaken judgement of a speaker's credibility." (ibid, p. 21)

However, Frankfurter's inability to believe Karski's testimony does not seem to fit in with this analysis. It is not Karski's status as a knower that is being challenged; and, in an important sense, it is not Karski who is wronged. Yet nor is it the case that Frankfurter's inability to believe him can be described as an "innocent error". There seems to be something ethically significant at stake here; something, indeed, deeply ethically troubling. A further consideration of the conceptual framework of epistemic injustice can help us see just how troubling it is. In cases of epistemic justice, Fricker says, the "ethical poison of testimonial injustice must derive from some ethical poison in the judgement of the hearer." (ibid, p. 22). In other words, in cases where, for example, a witness is not believed because he is Black, the background assumptions and beliefs of the hearer are not just factually inaccurate, but are tainted with some "ethical poison" that leads the hearer to form an epistemic judgement about the testimony which constitutes a form of injustice. The moral import of these cases lies not just in the wrong that is done to the testifier in his capacity as a knower, but in the background beliefs themselves. 
What, though, was the background web of beliefs and judgement that led to Frankfurter's inability to believe Karski? A full answer to this question requires a deeper exploration of the relevant interconnections between moral belief and epistemic judgement. Yet, as I will go on to discuss, such an exploration suggests not only that, as Fricker's work has shown, a morally flawed and reprehensible set of beliefs can lead to an epistemic and moral failing; but troublingly - that a morally desirable set of beliefs can do so.

There are many personal, political and historical facts about Frankfurter and his context that must surely play a role in any full account of this incident. It is undoubtedly true, for example, that there were political interests at stake and that Karski was only too aware of these. Yet without denying the centrality of these factors as explanations for Frankfurter's behaviour, I want to focus on an ethically significant aspect of his response to Karski that I think offers an important way of making sense of this response, and that raises significant philosophical and educational questions. At the time of Karski’s report, although the Nazi programme for exterminating the Jews of Europe was well underway, details about its full extent and systematic nature were simply not common knowledge. Yet the relevant point for the present discussion is that, for Frankfurter - and he was certainly not unusual in this regard - the kinds of actions that characterised the implementation of this programme were beyond the realm of what could have previously been imagined as a description of human behaviour, even during wartime. This is not to say that the Holocaust of the Jews of Europe was the first incidence of genocide in human history. But irrespective of the argument that Frankfurter could, and perhaps should, have known about other genocides, some in the not-so recent past, I think it is reasonable to assume not only that he did not, but that the scale of atrocity and the level of brutality captured in Karski's descriptions was, for him, simply unimaginable.

The crucial point here is that Frankfurter's inability to believe Karski is not just an epistemic failing. It is not just an "innocent error" resulting from a simple lack of factual information, 
but is inseparable from a moral outlook. Yet unlike the "ethical poison" that is responsible for cases of testimonial injustice, the moral outlook in question here is, surely, a positive, not a negative one. It is a moral outlook that assumes that the world we live in is not one in which human beings can brutalise other human beings to the point that they lose all vestiges of humanity; in which soldiers can force hundreds of innocent men, women and children, at rifle-point, into freight cars coated with quicklime and leave them to die in agony (see Karski, 2011, pp. 368-384).

And herein lies the troubling implication: Could it not be the case that an apparently morally benign belief about the world we live in could lead to an epistemic failure - an inability to believe - which itself has terrible moral consequences? If this is the case, in what way can we account for Frankfurter's response as a moral failing?

\section{DENIAL}

The analysis of this case troubles some of the conceptual connections made in philosophical accounts of epistemic justice. Yet perhaps these accounts are the wrong place to look in trying to make sense of Frankfurter's response and its ethical significance. Perhaps this incident is best thought of not through the lens of philosophical work on epistemic justice, but through the lens of psychological theories of denial.

Yet here too, the academic literature leaves us strangely unable to fully capture the troubling aspects of this case. Classic cases of denial involve instances where the information presented to us is too psychologically disturbing to accommodate. This can take different forms and, as psychoanalytic theory has shown, can be both conscious and unconscious. A form of 
conscious denial, much discussed in the literature on public passivity and bystander behaviour (see for example Cohen, 2001; Seu, 2013; Staub, 1993) is "the deliberate choice not to expose ourselves to certain unpalatable information. We cannot live in a state of continuous awareness of the fact that thousands of children are starving to death every day [...] this is like taking a different route to avoid seeing homeless beggars in the streets." (Cohen, 2001, p.4).

Here, though, the denial is not the same as an inability to believe. The person who takes a different route home to avoid seeing homeless people is not having a hard time believing that such things as homelessness or dire poverty exist; she simply does not want to be reminded of them, or to believe that they happen here, in her home town. She allows herself to consciously create the illusion of a world in which such things cannot exist, although she knows full well that they can. A similar distinction is at work, I think, in classic cases of (often subconscious) denial in which relatives of victims of sexual abuse, or even the victims themselves, cannot confront the full reality of what is happening. Here, again, what is at stake is not the belief in a world in which it is possible, for example, to conceive of men sexually abusing their own daughters, but the belief that it could be my husband doing this.

The difficulty experienced by Frankfurter, however, is, I want to suggest, different from the difficulty we may have in accepting the evidence of something whose truth would have uncomfortable consequences for us, as explained in psychoanalytic theory, where denial is "understood as an unconscious defence mechanism for coping with guilt, anxiety and other disturbing emotions aroused by reality. The psyche blocks off information that is literally unthinkable or unbearable." (Cohen, 2001, p. 5). 
Denial, Cohen says, can be either literal - refusal to acknowledge the facts; interpretive giving them a different meaning ("It was not rape"; "I am a social drinker, not an alcoholic"); or implicatory (“it's nothing to do with me.") (ibid, pp. 7-9).

The Karski case seems to be a case of literal denial, yet its motives, I suggest, are not those typically ascribed to agents in psychological theories of denial. What Frankfurter is struggling to preserve here is not a sense of his self-image or the virtuousness of people close to him, but rather the very moral grammar of the world as he knows and understands it.

Cohen refers to the Holocaust several times in his work, noting that when reports about the Nazi genocide started coming out, "Observer governments refused to believe clear reports about the annihilation programme." (ibid, p. 14). In this case there was possibly, he says, "a zone of denial shared with the victims: the refusal to acknowledge a truth which seemed too impossible to be true.” (p. 14). There is, though, an important ethical aspect to this "impossibility" which goes unremarked in accounts that emphasise the psychological and cognitive mechanisms behind denial and the morally reprehensible consequences of such denial in the case of witnesses, bystanders or perpetrators of atrocities.

\section{THE HOLOCAUST AND EVIL}

Habermas, commenting on the Holocaust, says "Something happened there that no one could previously have thought even possible. It touched a deep layer of solidarity among all who have a human face. Until then - in spite of all the quasi-natural brutalities of world history we had simply taken the integrity of this deep layer for granted. At that point a bond of naivete was torn to shreds..." (in Geras, 2003, p. 27). 
Such remarks are not intended to single out the Nazi Holocaust as occupying a place somehow outside the rest of human history, but merely to capture the moral horror it arouses due to its totalising nature. In his careful and insightful discussion of the "Historikerstreit" controversy in the 1980's and the ongoing debates about the "uniqueness" of the Holocaust, Geras argues that the Holocaust "bears a moral horror unparalleled by other crimes and disasters, not through any single feature of it, but because of a cluster of features which combined into a frightening precedent, an appalling permanent possibility for the future of our species: the production of death as an order of being [...]" (ibid, p. 51), but makes the important point that this does not imply a mysterious, "inexplicable and transcendent mystery" attaching to the event. (ibid, p. 31). Nor does it imply that the Holocaust cannot be discussed and taught alongside other instances of genocide.

Both the literature on denial and literature on the Holocaust, then, support the idea that part of the reason for Frankfurter's inability to believe Karski - an inability which had nothing to do with his perception of Karski as a credible witness - was the "unthinkable" nature of what he was describing. This idea of the unthinkable, though, cannot be captured simply through an analysis of which features of the Nazi Holocaust went beyond any previously known instances of genocide, either in their scale or in their intent. The ethical issue here is not captured in the point, noted by Cohen, that "expectations for the future are built on familiarity with the past. It was hardly possible to foresee extermination or gas chambers when they had never been heard or conceived of." (Cohen, 2001, p. 140-141). This deeper ethical significance is, in fact, partly what I believe Primo Levi is getting at when he says: "Things whose existence is not morally possible cannot exist”. (Levi, 1987).

\section{THE MORALLY UNTHINKABLE}


What Levi is invoking here is an idea of the morally unthinkable, an idea which has echoes in the philosophical work of Bernard Williams and Raimond Gaita.

Gaita develops the idea of "forms of the unthinkable" as part of his criticism of the kind of moral philosophy that, exemplified in the work of Peter Singer, exhorts us to follow a logical argument through to possibly morally repugnant conclusions. There are some things, Gaita argues, that are "unthinkable":

...unthinkable not in the sense that no one ever thinks them, but in the sense that they are beyond argument; they are 'indefensible' because any serious attempt to defend them would show one to lack the judgment necessary for the proper exercise of reason on the matters in question. Or, in the case of moral matters, because it is wicked even to contemplate them. (Gaita, 1998, p. 181).

A similar idea can be found in Gaita's development of the notion of moral seriousness. As Gaita explains: "The fear of reaching a morally horrible conclusion - the fear of becoming the kind of person who has seriously embraced it and will take it into her life $-[\ldots]$ is inseparable from, indeed is partly constitutive of, what it is to be a morally serious thinker, morally serious as a thinker [...]. " (Gaita, 2006, p. 6; see also Gaita, 1991, pp. 313-334).

Bernard Williams' notion of the "morally unthinkable", which he develops as part of his well-known critique of Utilitarianism (Smart and Williams, 1973), is different in significant aspects from Gaita's account. Yet they agree in their concerns about the "thinness" of moral philosophy, and Gaita draws on Williams' discussion in developing his account of evil (see Gaita, 1991, p. 21). However, the notion of the unthinkable described by Gaita and Williams leaves out - like much moral philosophy - the important educational dimension. Gaita refers 
repeatedly to "we", "our understanding" and "people"; yet it is clear that the "people" in question are adults. The educationally significant and unasked questions here concern not just how people come to regard certain deeds and thoughts as "unthinkable" in the first place, but also the possible epistemic consequences of a form of moral education or moral development in which the morally unthinkable plays a central role. Gaita's notion of the morally unthinkable is connected to his defence of the category of evil as a moral reality that is, as Kevin Surin puts it (Surin, 1986, p. 84), "extra-territorial to reason"; in other words, a reality that, while it would be unthinkable to deny it, cannot be established by reason alone.

It is here that one sees the parallels between Gaita's moral philosophy and the work of Wittgenstein. Although, as Nigel Pleasants points out, Wittgenstein "wrote nothing on ethics in his later work" (Pleasants, 2008, p. 245), Pleasants' own compelling reading of On Certainty suggests an ethical perspective with significant relevance for the current discussion. On Pleasants' reading, there are clear parallels between what he calls, following Daniele Moyal-Sharrock, "basic moral certainties", and Wittgenstein's position that "what underlies our epistemic practices and capacities is not itself an epistemic practice or capacity, nor items of certain knowledge, but something of a quite different kind, namely, our fundamental ways of being and acting in the world." (ibid, p. 251). Basic moral certainties, such as the wrongness of killing, Pleasants argues, can, like Moore's assertion that he knows that the hand he is holding up exists, "look like empirical knowledge claims but cannot actually be treated as propositional knowledge" (ibid, p. 250). Our moral certainty about the wrongness of certain acts, such as killing an innocent person, is a form of certainty that "is not, and cannot be, expressed via propositions of affirmation or confirmation. Rather, it is manifest in how we live and conduct ourselves..." (ibid, p. 263, my emphasis). As Wittgenstein puts it in On

\section{Certainty:}

"it is not based on grounds. It is not reasonable (or unreasonable). 
It is there - like our life" (Wittgenstein, 1979, 559).

The relevance of this account of moral certainty for the present discussion lies in the implication that, if moral certainties constitute, for most people, not simply propositions that they can logically defend, but "fundamental ways of being and acting in the world", then perhaps the encounter with an account of the world in which these fundamental ways of being and acting have apparently been abandoned on a massive scale, becomes so emotionally and psychologically destabilising that one is unable to accept it. Gaita explicitly draws on this Wittgensteinian insight in his discussion of "forms of the unthinkable", where he talks of "regularities" of our everyday practices that "condition the concepts used in our reasoning, rather than providing support for it". (Gaita, 1998, p. 166). For Wittgenstein, "My life shows that I know or am certain that there is a chair over there, or a door, and so on. - I tell a friend e. g. "Take that chair over there", "Shut the door", etc. etc. (Wittgenstein, 1979, 7).

In the context of the present discussion, the crucial and troubling issue is the possible connection between the category of the morally unthinkable as constitutive of being an ethical thinker, as part of "the foundation of our ethical practices and the scaffolding or framework of moral perception, inquiry, and judgement" (Pleasants, 2008, p. 254); and the confrontation with the reality of evil on such a scale that it suggests that this foundation has collapsed. It is important to note that, as D.Z Phillips explains in his discussion of Gaita's work, there is nothing in the notion of the morally unthinkable to suggest that people cannot or do not do things that most members of a moral community would consider unthinkable. Indeed, the very significance of what Phillips describes as "the logical space occupied by the notion of 'unthinkability' in ethics" is that it "marks a moral limit in one's thinking; it is itself an expression of the recognition of the evil that is being done" (Phillips, p. 62). Thus "to say 
'he treats her in unthinkable ways' is not to deny the facts about how he treats her, but to express one's moral reaction to them." (ibid).

These remarks suggest that perhaps the question of scale is relevant to the connection between our ethical practices and certainties and our epistemic state. If what is being described is a mass, collective treatment of other human beings in unthinkable ways, then the implication that the category of the unthinkable has in fact been abandoned can, in light of the above Wittgensteinian insights, be something so destabilising that it becomes impossible to believe it. Believing such a thing would constitute not simply an acceptance of the truth of an empirical proposition, but rather a shift in the "scaffolding" of our everyday ethical practices.

There seem to be (at least) two inter-connected questions here in the context of Karski's encounter with Frankfurter. One is the psychological question of whether being a person for whom the category of the morally unthinkable is constitutive of one's way of being in the world makes one likely to assume that this category is equally constitutive for others. If so, this psychological state would at least partly explain the difficulty of believing reports of what appears to be an absence of this category on a previously unheard of scale, amongst an entire community of fellow human beings. Connectedly, the Wittgensteinian idea of moral certainties constituting "our fundamental ways of being and acting in the world" accounts for the totally destabilising effect of the suggestion that the very form and shape of the world as we know it, that constituted our ways of being, is not in fact as we thought it to be.

Acknowledging the reality of the Nazi genocide, in this sense, means not just accepting the truth of a proposition about the existence of evil in the world, but somehow abandoning the 
very categories, concepts and certainties that constitute our way of being in the world and our perceptions about the kind of world we share. This is an insight that emerges too from the literature on the testimonies of Holocaust victims, as I will discuss below. Both these points, I suggest, raise important educational questions.

If it is possible that fully embracing the category of the morally unthinkable as a part of who one is and how one lives will lead to the belief that this category plays a similarly central and salient role in the lives of the people with whom one imagines one shares a moral universe, then could it perhaps be something like this process that partly explains Frankfurter's inability to believe Karski?

In her account of testimonial injustice, Fricker, as mentioned above, explains how "the ethical poison of testimonial injustice must derive from some ethical poison in the judgement of the hearer" (Fricker, 2007, p.22). Yet for Frankfurter, if the above account is correct, accepting the truth of Karski's testimony would itself constitute a kind of "ethical poison" in that it would allow his moral universe to be poisoned by the thought that what was previously morally unimaginable, beyond moral discussion, was now fully imaginable and describable.

Of course the historical context is crucial in gaining further insight into the educational implications of this case. Part of the explanation for Frankfurter finding what Karski was describing unthinkable is not available to us in a post-Holocaust reality. We can no longer claim that genocide on a mass scale, the brutalising of innocent people, often by their neighbours, is not possible, given the mass of evidence (evidence that, importantly, includes more than just oral testimony) from both the Nazi Holocaust and more recent instances of genocide. Yet the Wittgensteinian insight developed by Gaita suggests that even in the face of such evidence, to accept reports of such brutality without any kind of mental and emotional struggle would be in some sense morally disturbing. For the moral import of 
Frankfurter's inability to believe Karski reflects a fundamental rootedness in a certain understanding of what a moral human world looks like, one which made what Karski was describing unthinkable. So although on one level, a failure to believe reports of genocide today would be an epistemic failing of grave moral significance, on another level, there is an aspect of Frankfurter's inability to believe which still seems essentially a morally valuable one: one of refusing to make the morally unthinkable thinkable.

In a way, then, the case of Frankfurter may help us to imagine not just what would, but what should be the appropriate moral response of a child on learning for the first time of the horrors of genocide or other appalling cases of abuse and dehumanisation. Can we, at one and the same time, ensure that children, on learning about the brutal actions of human beings towards other human beings, will react in a way which reflects the sense that such acts are morally unthinkable; and ensure that they confront and believe the evidence of their existence?

\section{HOLOCAUST EDUCATION}

I want to suggest that the insight that the category of the morally unthinkable is an important, indeed constitutive aspect of our ethical life, invites a fairly radical rethinking of many familiar stated aims of Holocaust education.

Many writers on Holocaust education have defended the view that teaching the Holocaust will in itself somehow lead to better moral understanding and moral sensitivity. Thus Archbishop Desmond Tutu, in his forward to The Encyclopaedia of Genocide (Charny, 1999), writes: 
The compelling reason why we should learn about the Holocaust, and the genocides committed against other peoples as well, is so that we might be filled with a revulsion at what took place and thus be inspired, indeed galvanized, to commit ourselves to ensure that such atrocities should never happen again.

But this surely cannot be true; learning about the Holocaust cannot in itself fill us with revulsion. Such revulsion is only possible if we have a prior moral understanding of what is thinkable and unthinkable. To put it in Gaita's terms, the revulsion is expressive of the constitutive nature of our category of the morally unthinkable.

Likewise, many writers on Holocaust education have focused on the need to understand the effects of totalitarian regimes, the psychological mechanisms of dehumanisation, and the mindset of rescuers and bystanders as well as perpetrators. Such understanding is seen as integral to the aim of preventing future atrocities. As Berel Lang puts it, the crucial "lesson" here is "that the intention to commit genocide might develop incrementally rather than being fully formed at the outset; that since the Holocaust happened once, something like it can happen again; that with respect to genocide there are no legitimate bystanders." (in Blum, 2003, pp. 263-4).

Developing such an understanding may be a legitimate and worthy task for historians, but it is not, I would argue, the primary task of educators. For before we can even begin to undertake or engage in such historical understanding, we need, as Primo Levi reminds us, to focus not on the "lessons to be learned" about the intentions and motives of the perpetrators, but on the utterly evil nature of the experience of the victims. Yet the truly "unthinkable" nature of this experience will only carry a deeply moral significance if it rests on a prior immersion in an understanding of the moral universe as one in which such experiences are, in a real sense, "unthinkable". 
Indeed, a focus on the mechanisms by which evil was able to be done and to go unchecked may distract us from the educationally important task of preserving the notion of the morally unthinkable. This suggests a disconcerting challenge not only to narratives of Holocaust education which construe it perhaps simplistically in terms of "lessons to be learned", but to the more subtle approach reflected in the work of Hannah Arendt, in her famous (and famously misunderstood) notion of the banality of evil.

To call evil banal, Susan Neiman says, commenting on Arendt, is to imply "that the sources of evil are not mysterious or profound but fully within our grasp. If so, they do not infect the world at a depth that could make us despair of the world itself. Like a fungus, they may devastate reality by laying waste to its surface. Their roots, however, are shallow enough to pull up.” (Neiman, 2004, p. 302). Arendt's outlook, Neiman suggests, is at its core an optimistic one, as reflected in her comments on the story of Anton Schmidt, a German soldier who sacrificed his life to help Jewish partisans, related during the Eichmann trial:

The lesson of such stories is simple and within everybody's grasp. Politically speaking, it is that under conditions of terror most people will comply, but some people will not $[\ldots]$ Humanly speaking, no more is required, and no more can reasonably be asked, for this planet to remain a place fit for human habitation. (Arendt, in Neiman, ibid).

I used to find Arendt's analysis compelling. But in light of my reflections on the Karski case, I now wonder: is it possible to maintain a theodicy according to which evil is explicable and banal, and at the same time to preserve the view that some things are morally so abhorrent that they are, in an important sense, unthinkable? There is, I suggest, a tension here. To react to testimonies of the evil perpetrated by the Nazis in a way which acknowledges the full extent in which they take us beyond our sense of what is morally 
thinkable is to abandon the attempt to offer an account of them that sits within the moral grammar of our everyday lives. As Lawrence Langer notes, reflecting on the experience of listening to testimonies of Holocaust survivors:

I ask myself what we can do with such information, how we can inscribe it in the historical or artistic narratives that later will try to reduce to some semblance of order or pattern the spontaneous defilement implicit in such deeds? Where shall we record it in the scroll of human discourse? How can we enrol such atrocities in the human community and identify them as universal tendencies toward evil inherent in all humankind? (Langer, 1998, p. 2).

His response, contra Arendt, is the following:

Well, we can't: we require a scroll of inhuman discourse to contain them; we need a definition of the inhuman community to coexist with its more sociable partner, and in their absence, we turn by default to more traditional forms of expression. The results may be comforting, but what price must we pay for such ease? The alternative is to begin by accepting a reality that escapes the bounds of any philosophy or system of belief that we have cherished since our beginnings, and to pursue the implications of this unhappy admission wherever they may lead. (ibid).

The question is not whether the fact of the Holocaust allows us to carry on believing, as Arendt did, that "the world as God created it seems to me a good one" (Neiman, 2004, p. 302), or whether it forces us to reject this view of the world. For attentiveness to the experience of victims of genocide, against a background in which certain things are unthinkable, upsets our very moral language and frameworks for thinking about the world. 
Arendt herself was perhaps aware of this, as Laura Bilsky (2001, p. 247) notes:

Arendt fears that oral testimonies by survivors will open the door to the suffering of the victims - a suffering that has no measure and that cannot be comprehended. She came to Eichmann's trial with the hope that the legal categories would provide some measure of understanding. The only hope of achieving such understanding, Arendt wrote, is by concentrating on the acts of the accused, not on the immeasurable suffering of the victims.

Yet it is precisely the "immeasurable suffering of the victims" that must be heard and confronted if we are to appreciate the full significance of the Holocaust. It is here that the complexity of the educational questions prompted by the Karski case lies: the reaction of disbelief to reports of evil of the nature described by Karski is, I have suggested, somehow ethically appropriate and valuable. Yet it is ethically appropriate and valuable precisely insofar as it rests on a form of moral certainty - according to which some things are unthinkable - that constitutes "our fundamental way of being in the world". The educationally important - and possibly contradictory - task, then, is both to ensure that children are immersed in a moral world in which certain things are morally unthinkable, and to convey the full horror of the experience of victims of genocide in a way that captures why and how it represents something truly unthinkable, while at the same time ensuring that its truth is never doubted.

It is important to note that the idea of the morally unthinkable is not equivalent to the notion of a moral principle which it is impossible to imagine overstepping. The stories related by survivors are not just "unthinkable" in that they reflect a moral failure on the part of individual agents. Langer's painstaking analysis of the testimonies of Holocaust survivors 
shows how truly listening to these stories reveals a reality that is "unthinkable" in a way far deeper and more disconcerting than the idea of moral transgression. His description of these testimonies reveals how engaging with their words on their own terms leaves us almost without a language to contain them. Within these narratives, the very categories of temporal time, death and life, take on a totally different meaning. Listening to Holocaust testimonies, Langer says, "You imagine you can design a new template of evil to gain insight into the motives that lead to mass murder..." but then "you are left adrift on an alien idea without a moral compass.” (Langer, 1998, p. 78).

This is not, though, to argue, as some theorists have, that the horrors of the Holocaust are "beyond the limits of ordinary thought and analysis" (Laqueur, 2002, p. 10). This point is exemplified in the work of Primo Levi, the most unflinching narrator of the experience of the Holocaust who, as Laqueur says (ibid) "prided himself on being able to write and talk about the camps in limpid, even clinical prose", insisting that "what he witnessed was not 'unspeakable', 'ineffable', 'beyond language'”. Levi himself says in his last book, "I never liked the term 'incommunicability', so fashionable in the 1970s”. (Levi, 1989, p. 94).

It is Levi, too, who expresses the ethically and educationally troubling tension at the heart of the issues of testimony and the morally unthinkable that I have been exploring here. In the Preface to The Drowned and the Saved, he recounts how S.S. soldiers in Auschwitz used to amuse themselves by cynically assuring prisoners that even if some of them survived the Nazi camps, no one would ever believe their stories about what went on inside. Yet of course the very power of these assurances lay precisely in the knowledge that, outside the world of Auschwitz, there were still people - most people, perhaps - living in a world in which such things were unthinkable; a world in which the contours of their moral language still felt solid. 
Langer notes "I have taught students about [the Holocaust] for nearly thirty years, and incredulity remains a constant factor in their response", (Langer, 1998, p. 196). Yet to the extent that this response has both an epistemic and an ethical dimension, then surely it would be morally troubling if it were not common ${ }^{1}$. The fact that it is suggests that these students' moral universe is a sound one. Langer's response, as an educator, to such incredulity at stories which "affront the moral imagination" (ibid, p. 194) is to say "If some forms of human misery do indeed still lie beyond our powers to comprehend, it would be irresponsible to allow our psychological and intellectual hesitation to estrange us from that misery. The only alternative, a complex and difficult one, is to find ways of making the inconceivable conceivable until it invades our consciousness without meeting protest or dismay". (ibid, p. 65.) The educational task, though, begins before this "complex and difficult" one. Although this is not primarily a paper on moral education, one insight suggested by this discussion is simply, to paraphrase Paul Goodman's view that "there is no right education except growing up into a worthwhile world" (Goodman, 1962, p.59), that perhaps there is no right moral education except growing up into a moral world. The fact that there are many children who do not live in anything like a moral world; children who grow up in war-zones, or who experience horrific abuse and violence, just reinforces the urgency of this task. Yet, as the above discussion has illustrated, there is a tension between this undeniable ethical task of the educator, and the knowledge that our very success at it may make the task described by Langer even more complex and difficult.

Adorno (2003) famously remarked that "the premier demand upon all education is that Auschwitz not happen again." Yet there is no straightforward move from this moral imperative to any specific programmes for Holocaust education. I hope to have shown that

\footnotetext{
1 I am distinguishing this kind of response from the ideologically motivated response of Holocaust denial. There is clearly much more to be said on this issue that I cannot pursue here.
} 
the connections between the ethical and epistemic aspects of what we believe, why we believe it, and their educational implications, are far more complex than the literature on epistemic justice, on denial, on the morally unthinkable, and on Holocaust education can account for.

Miranda Fricker has contributed to "the revelation of a certain ethical dimension to epistemic life" (Fricker, 2001, p. 1), and her work highlights the need to overcome the social, political and psychological obstacles that lead to injustice in our epistemic practices. Recent cases like the Rotherham sex abuse scandal show just how much is still to be done in this area. Yet there are, I have suggested, significant ethical dimensions to our epistemic life that go beyond issues of justice.

There is far more philosophical work to be done in exploring these dimensions and their educational significance. The present paper has offered only tentative suggestions as to the directions that such work could take. If what the above account suggests about the relationship between our moral beliefs and our epistemic judgements is true; if Frankfurter's inability to believe Karski is at one and the same time ethically understandable - even desirable - and ethically and epistemically disastrous, then the situation of the educator is one of irresolvable tension. That the very moral universe we strive to create for children can lead to their inability to believe certain things; that the inability to believe is both morally understandable and unforgivable is a disturbing idea that perhaps Karski himself was painfully aware of.

\section{KARSKI AND EPISTEMIC JUSTICE}


I said in my initial account of Karski's testimony that the concept of epistemic injustice cannot capture the troubling issues raised by this case as, to the extent that there was any injustice in Frankfurter's response, it was not an injustice that was done to Karski in his capacity as a knower. Indeed, one could argue, the injustice was not towards Karski at all, but to the millions of people who perished in the Holocaust and whose lives, perhaps, could have been saved had world leaders intervened sooner. But maybe there is more to be said here. In Lanzmann's film Shoah, Karski is interviewed in his Washington home about what he witnessed in the Warsaw Ghetto over forty years previously. He is elegant, eloquent and composed. Yet just seconds into the interview, he loses his composure and gets up from the sofa, tears streaming down his face, signalling to the camera crew to stop filming. His weeping can, perhaps, be seen as a simple expression of his humanity; the same humanity that accounted for his outrage at the brutalisation he witnessed in the Warsaw Ghetto, and that led him to risk his life in an attempt to halt it (see Karski, 2011). But his weeping is not just evidence of the fact that, as he wrote in 1942, "The images of what I saw in the death camp are, I am afraid, my permanent possessions" (ibid, p. 382). It is also, surely, evidence of his lasting despair and anger at not being believed and thereby, however indirectly, failing to prevent further atrocities. In this sense, then, there is a kind of injustice done to Karski; yet what is at stake is not his capacity as a knower, but his impossible and inescapable burden of both conveying the unthinkable and making it thinkable. Karski’s anguished weeping, I think, expresses not just the painful memory of what he witnessed, but his recognition of the awful inevitability of the fact that the inability to believe the true horror of what he had witnessed was a constitutive part of its moral significance.

That our inability to think the morally unthinkable could lead to a failure to accept the truth of a reality that demands a moral response from us is a disturbing idea, the chilling force of which is captured in Primo Levi's description of life in the Lager: 


\begin{abstract}
Almost all the survivors, orally or in their written memoirs, remember a dream which frequently recurred during the nights of imprisonment, varied in its detail but uniform in its substance: they had returned home and with passion and relief were describing their past sufferings, addressing themselves to a loved one, and were not believed, indeed were not even listened to. In the most typical (and cruelest) form, the interlocutor turned and left in silence. (Levi, 1989, p. 2).
\end{abstract}

\title{
Acknowledgements
}

I would like to thank Oliver Belas, Steinar Boyum, Walter Okshevsky, Nick Peim and Caroline Wilson for their thoughtful and supportive comments on this paper, both in its early stages and when I presented it at the PESGB conference in March 2015. I am especially grateful to Rafal Godon for opening the door that led me to Poland, and to the remarkable story of Jan Karski and the Polish resistance.

\section{References}

ADORNO, T. W. (2003) Can One Live After Auschwitz?: A Philosophical Reader (California, Stanford University Press).

BILSKY, L. ( 2001) Between Justice and Politics; The Competition of Storytellers in the Eichmann Trial, in S.ASCHHEIM (Ed.) Hannah Arendt in Jerusalem (Berkeley, California University Press).

BLUM, L. (2003) The Holocaust in American Life as a Moral Text, in E. GARRARD and G. SCARRE, Moral Philosophy and the Holocaust (Aldershot, Ashgate). 
CHARNY, I. W. (1999) The Encyclopaedia of Genocide (Jerusalem, The Institute on the Holocaust and Genocide).

COHEN, S. (2001) States of Denial; Knowing About Atrocities and Suffering (Cambridge, Polity Press).

FRICKER, M. (2007) Epistemic Injustice; Power and the Ethics of Knowing (Oxford, Oxford University Press).

GAITA, R. (2006) “Torture, Public Reasons and Political Education”, Keynote Lecture at the Philosophy of Education Society of Great Britain annual conference, New College, Oxford, $31^{\text {st }}$ March-2 $2^{\text {nd }}$ April.

GAITA, R. (1998) A Common Humanity; Thinking About Love and Truth and Justice Abingdon, Routledge).

GAITA, R. (1991) Good and Evil: An Absolute Conception. (Basingstoke, Macmillan).

GERAS, N. (2003) In a Class of its Own? in E. GARRARD and G. SCARRE, Moral Philosophy and the Holocaust (Aldershot, Ashgate).

GOODMAN, P. (1962) Compulsory Miseducation and The Community of Scholars (New York, Vintage Books).

KARSKI, J. (2011) Story of a Secret State (London, Penguin Classics). 
LANGER, L. (1998) Preempting the Holocaust (New Haven, Yale University Press).

LAQUEUR, T. (2002) "Travelling in the Classic Style" (Review), London Review of Books, Vol. 24: 17.

LEVI, P. (1989) The Drowned and the Saved (London, Abacus).

LEVI, P. (1987) “Beyond Judgement”, New York Review of Books, $17^{\text {th }}$ December, 1987.

NEIMAN, S. (2004) Evil in Modern Thought; An Alternative History of Philosophy (Princeton, Princeton University Press).

PHILLIPS, D.Z. (2003) Minds, Persons and the Unthinkable, in A. O'HEAR (Ed.) Minds and Persons (Cambridge, Cambridge University Press).

PLEASANTS, N. (2008) Wittgenstein, Ethics and Basic Moral Certainty", Inquiry: An Interdisciplinary Journal of Philosophy, 51:3, pp. 241-267.

SEU, B. (2013) Passivity Generation; Human Rights and Everyday Morality (Basingstoke, Palgrave Macmillan).

SMART, J.J.C. and WILLIAMS, B. (1973) Utilitarianism: For and Against (Cambridge, Cambridge University Press). 
STAUB, E. (1993) “The Psychology of Bystanders, Perpetrators, and Heroic Helpers”, International Journal of Intercultural Relations, 17, pp. 315-341.

SURIN, K. (1986) Theology and the Problem of Evil (Oxford, Blackwell).

WITTGENSTEIN, L. (1979) On Certainty (Oxford, Blackwell).

WOOD, E. T. and JANKOWSKI, S. M. (1996) Karski: How One Man Tried to Stop the Holocaust (New York, Wiley and Sons). 